\title{
Membangun Semangat Kebangkitan Nasional melalui Konten Pendidikan Agama Kristen Multikultural
}

\author{
Rita Evimalinda1, Rikardo Dayanto Butar-butar², Efvi Noyita ${ }^{3}$ \\ 1,2,3Sekolah Tinggi Teologi REAL, Batam \\ 1ritaevi@sttrealbatam.ac.id,2rikardobutar@gmail.com, \\ 3efvinoyitapermata@gmail.com
}

\begin{abstract}
Religious sentiment, identity, has been a major component in so many conflicts in Indonesia. Ironically, educated people and young people become perpetrators of social violence. Various conflicts have weakened diversity, solidarity as a plural country and must be stopped through the interaction of teaching religious education in schools. This paper is qualitative literature to explain how to interpret and build the spirit of national awakening through Christian religious education in schools. The findings of the substance of the spirit of national awakening today are making various kinds of changes for a better condition. The learning content of multicultural Christian Religious Education (CRE) contains the values of the spirit of national awa-kening including the following aspects: (1) CRE for peace, (2) CRE for harmony, (3) CRE for prosperity, (4) PAK for tolerance. Teachers in teaching PAK in schools should use a constructive approach where students are encouraged to take their roles for prosperity, peace, unity and national unity. So that the function of believers to be the light and salt of the world is realized and has an impact on the revival of the Indonesian nation.
\end{abstract}

Keywords: national awakening; nationalism; multicultural; Christian education

Abstrak. Sentimen agama, identitas, telah menjadi komponen utama dalam begitu banyak konflik di Indonesia. Ironisnya kaum terpelajar dan kaum muda menjadi pelaku aksi kekerasan sosial. Berbagai konflik telah melemahkan keberagaman, solidaritas sebagai negara majemuk dan harus dihentikan melalui interaksi pengajaran pendidikan agama di sekolah. Tulisan ini merupakan kualitatif literatur untuk memaparkan bagaimana memaknai dan membangun semangat kebangkitan nasional melalui pendidikan agama Kristen di sekolah. Hasil temuan subtansi semangat kebangkitan nasional zaman sekarang adalah melakukan berbagai macam perubahan untuk suatu kondisi menjadi lebih baik. Konten pembelajaran Pendidikan Agama Kristen multikultural mengandung nilai- nilai semangat kebangkitan nasional meliputi aspek:(1) PAK untuk kedamaian, (2) PAK untuk kerukunan, (3) PAK untuk kemakmuran, (4) PAK untuk toleransi. Guru dalam mengajar PAK di sekolah hendaknya menggunakan pendekatan konstrukif dimana peserta didik didorong mengambil perannya untuk kemakmuran, perdamaian, persatuan dan kesatuan bangsa. Sehingga fungsi orang percaya menjadi terang dan garam dunia terealisasi dan berdampak pada kebangkitan bangsa Indonesia.

Kata kunci: kebangkitan nasional; nasionalisme; multikultural; pendidikan Kristen 


\section{PENDAHULUAN}

Indonesia, jika dilihat dari latar belakang etnis, sosial budaya, bahasa, dan agamanya tak terelakkan memiliki perbedaan-perbedaan. Oleh karena itu, kemajemukan bangsa Indonesia merupakan isu strategis, karena integrasi nasional merupakan landasan persatuan dan kesatuan bangsa, dan merupakan keharusan bagi terciptanya stabilitas nasional. Saat ini kita berada dalam masyarakat yang majemuk secara agama, budaya, suku, gaya hidup. Akan tetapi, tanpa disadari kemajemukan tersebut dapat menjadi sumber kekayaan nasional namun tidak dapat dipungkiri setiap perbedaan tersebut juga berpotensi konflik jika tidak disikapi dengan baik. Dampak pluralitas pada kehidupan sehari-hari memaksa kita untuk mencari cara baru dan memadai untuk memahami dan berhubungan dengan masyarakat dari tradisi agama lain. ${ }^{1}$

Berkaitan dengan hal itu, pendidik dan individu yang diajar memiliki tugas penting dalam membangun semangat kebangkitan nasional. Namun, realita yang kita temukan saat ini sangat memprihatinkan karena lambat laun semangat solidaritas dalam keberagaman sebagai nilai kebangkitan nasional mulai kabur. Berbagai konflik dan kekerasan yang mengatas namakan agama kerap terjadi. Melansir pemberitaan media massa online kompas.com di mana peristiwa yang membuat gempar masyarakat Indonesia pada Minggu, 28 Maret 202, yakni terjadinya ledakan bom di depan gereja Katedral Makasssar dan penyerangan Mabes Polri, dalam rentang waktu yang berdekatan. Ironisnya para pelaku teror yang terjadi saat ini melibatkan kelompok kaum muda. Fenomena isu pluralitas agama muncul di tengah-tengah ragam klaim kebenaran yaitu setiap agama mengaku sebagai yang paling nyata dan benar sedangkan agama lainnya tidak benar Thoha menulis dalam bukunya klaim ini seterusnya menghasilkan sebuah keyakinan ajaran keselamatan. Keyakinan ini juga berlaku pada sekte atau agama yang sama seperti Protestan dan Katolik, Hinayana dan Mahayana dalam agama Buddha maupun kelompok agama Islam. ${ }^{2}$ Maka penting untuk memandang kemajemukan agama sebagai sesuatu yang harus diterima dan disambut dengan baik sehingga tercipta stabilitas nasional. Jika tidak demikan eksistensi agama sebagai pembawa damai, rahmat dan kasih sayang akan dipertanyakan. Misalnya agama diberi label negatif yakni sumber konflik.

Karya tulis yang mengkaji relevansi kebangkitan nasional dan pendidikan agama yaitu penelitian Siti Muawanah yang meneliti nasionalisme melalui pendidikan agama Kristen dan Islam. Dengan kesimpulan untuk pendidikan agama Kristen, nasionalisme tidak secara tegas menjadi bahan pada pelajaran agama di sekolah SMA/SMK kelas XII. Namun ada materi yang sesuai dengan jiwa nasionalisme. Salah satu kompetensi yang dirumuskan khusus pembelajaran agama Kristen kelas-12 yaitu tanggung jawab Kristen dalam memahami demokrasi dan hak asasi manusia dalam

\footnotetext{
1 "Religious Plurality and Christian Self-Understanding," Word Council of Churches, n.d.

${ }^{2}$ Anis Malik Thoha, Tren Multikulturalme Agama: Tinjauan Kritis (Jakarta: Perspektif Kelompok GEMA INSANI, 2005).
} 
tindakan sebagai pemberita injil dan membawa kedamaian. ${ }^{3}$ Penelitian lainnya, Saragih yang membahas pendidikan agama Kristen berbasis karakter kebangsaan dengan mengarahkan Pendidikan Agama Kristen (PAK) dalam membentuk kemandirian iman peserta didik, keterbukaan dan memberikan pendidikan karakter kebangsaan. ${ }^{4}$

Penelitian-penelitian terdahulu tidak banyak yang membahas membangun semangat kebangkitan nasional dalam pendidikan agama Kristen. Harls Evan R. Siahaan memang menggagas perayaan Paskah dapat membangun rasa nasionalisme orang Kristen. ${ }^{5}$ Namun, apa yang dilakukannya belum menyentuh ranah pendidikan Kristiani. Oleh karena itu, tulisan ini mengeksplorasi pendidikan Kristiani, dan bagaimana orang Kristen bersikap di dunia yang majemuk secara agamis. Pembahasan pada artikel ini menjelaskan substansi kebangkitan nasional zaman sekarang, dan konten pendidikan agama Kristen multikultural. Temuan yang diharapkan adalah penjelasan deskriptif, sistematis dan analitis relevansi pendidikan agama Kristen multikultural dalam memelihara semangat kebangkitan nasional. Apabila pembelajaran PAK multikultural disampaikan, dan guru mendorong peserta didik terlibat aktif dalam kemajemukan untuk memahami dan menerima perbedaan, maka, setidaknya, dapat meminimalisasi konflik yang bernuansa SARA.

\section{METODE PENELITIAN}

Tulisan ini dihasilkan melalui riset kepustakaan (library research) dengan metode kualitatif deskriptif untuk memaparkan beberapa hal. Pertama, mengemukakan sejarah kebangkitan nasional dengan menggunakan literatur terkait. Kedua, melakukan studi Alkitab dnegan referensi terkait informasi dan ajaran tentang multikultural dalam Alkitab melalui narasi maupun ayat-ayat pendukung, baik dalam Perjanjian Lama (PL) maupun Perjanjian Baru (PB). Ketiga, meninjau konten Pendidikan Kristen yang bercirikan semangat kebangkitan nasional. Keempat, relevansi konten pendidikan agama Kristen multikultural dalam memelihara semangat kebangsaan

\section{PEMBAHASAN}

\section{Kebangkitan Nasional}

Kebangkitan nasional (pergerakan nasional) adalah masa semangat persatuan, kesa-tuan, rasa nasionalisme yang bangkit dalam memperjuangkan kemerdekaan. Hari pergerakan nasional juga merupakan dasar dari berbagai kesadaran yang memuncul-kan paham baru, yang dapat menggerakan semangat kebangsaan, semangat penyatu-an keragaman bangsa. Perjuangan berawal dari organisasi Budi

\footnotetext{
3 Siti Muawanah, "Nasionalisme Melalui Pendidikan Agama Pada Peserta Didik SMA/SMK/MA Di Wilayah Perbatasan Kalimantan Barat," SMART 1, no. 2 (December 16, 2015), http://blasemarang.kemenag.go.id/journal/index.php/smart/article/view/137-150.

4 Erman Sepniagus Saragih, "Pendidikan Agama Kristen Berbasis Wawasan Kebangsaan," Teologi Cultivation, Institut Agama Kristen Negeri Tarutung 2, no. 2 (2018),470-475 https://ejournal.iakntarutung.ac.id/index.php/cultivation/article/view/.

${ }^{5}$ Harls Evan Siahaan, "Mengajarkan Nasionalisme Lewat Momentum Perayaan Paskah: Refleksi Kritis Keluaran 12:1-51," DUNAMIS (Jurnal Teologi dan Pendidikan Kristiani) Vol 1, no. 2 (2017): 39-54, www.sttintheos.ac.id/e-journal/index.php/dunamis.
} 
Utomo, sebagai aso-siasi utama di masa pergerakan Indonesia, yang bebas dari prasangka keagamaan, namun lebih berpusat pada peningkatan pendidikan dan budaya. Program utama Budi Utomo adalah memajukan bangsa dan negara dalam kehidupan harmonis, teru-tama dalam memajukan Pendidikan. ${ }^{6}$ Pembentukan organisasi yang awalnya hanya terdiri dari penduduk pulau Jawa saja, terus bergerak menjadi sebuah organisasi yang besar dan menggerakan semangat baru dalam upaya terus melepaskan diri dari cengkraman kaum imperialisme. Namun Budi Utomo bukan satu-satunya organisasi yang bercirikan rasa kesadaran kebangkitan nasional. Karena masih ada organisasi lain sebelum Budi utomo terbentuk, yang juga memicu sikap patriotisme masyarakat Indonesia terhadap tanah air kita tercinta ini. ${ }^{7}$

Latar belakang sejarah gerakan Nasional memiliki arti penting dan menitikberatkan pada keseluruhan siklus peningkatan jiwa patriotisme Indonesia berasaskan kesamaan, dan keinginan memperjuangkan kebebasan rakyat. ${ }^{8}$ Peristiwa sejarah ini telah memberi kontribusi besar terhadap kehadiran sebuah negara bangsa (nation state) yang kemudian dikenal dengan nama Indonesia. Namun, bagaimana memaknai kebangkitan nasional di masa sekarang? Bonnie Triyana yang aktif menulis sejarah pergerakan Indonesia mengutarakan kebangkitan nasional harus dipahami menurut zamanya sehingga makna yang termaktub dari 'kebangkitan nasional' harus memberikan arti penting bagi kehidupan di zamannya, sehingga menggugah publik. Di masa sekarang harus dimaknai sebagai kesempatan untuk melakukan berbagai macam perubahan untuk perbaikan kehidupan lebih baik. Dalam versi senada Irawan menambahkan substansi suatu kebangkitan itu adalah suatu perubahan suatu kondisi menjadi kondisi lebih baik. ${ }^{9}$

Peran dunia pendidikan dalam tugas pembinaan membangun semangat kebang-kitan nasional pada peserta didik adalah sebagai alat untuk memperbaiki kehidupan sekarang dan selanjutnya untuk merencanakan generasi masa depan menjadi sema-kin baik, sejahtera dan menghargai kesetaraan sesuai dengan cita-cita luhur bangsa Indonesia. Pendidikan berbasis semangat kebangsaa yang diakomodir dalam bebe-rapa subjek pelajaran termasuk pendidikan agama harus menerapkan komitmen kebangsaan terhadap NKRI, Pancasila, kebhinekaan, serta menyadari adanya perbe-daan dalam suatu bangsa. ${ }^{10}$ Sehingga akan dihasilkan generasi muda yang menjadi terang dan berkat atas bangsanya (Yes. 60:1-2).

\footnotetext{
${ }^{6}$ Rury Yuliatri, "Membangun Semangat Kebangkitan Nasional Melalui Pendidikan", http://disdik.jabarprov.go.id/news/2166/membangun-semangat-kebangkitan-nasional-melaluipendidikan.

${ }^{7}$ Husaini Husda, "Rekonstruksi Sejarah Kebangkitan Nasional," Jurnal Adabiya 21, no. 2 (March 18, 2020): 31-45, https://jurnal.ar-raniry.ac.id/index.php/adabiya/article/view/6609.

8 Ayi B Santoso and Supriatna, Sejarah Pergerakan Nasional (Dari Budi Utomo 1908 Hingga Proklamasi 1945) (Bandung: UPI Bandung, 2018). hal 1

9 “Jejak Kebangkitan Nasional," Arsip Media Kearsipan Nasional (2014), www.anri.go.id. diakses 31 Maret 2021

${ }^{10}$ Edy Suandi Hamid, "Peran Pendidikan Untuk Mengukuhkan Nasionalisme Dan Membangun Karakter Bangsa," UNISIA 34 (2012), 40-46 https://journal.uii.ac.id/Unisia/article/download/5577/4997.
} 


\section{Multikultural dalam Alkitab}

Alkitab sebagai dasar Pendidikan Agama Kristen memberikan informasi yang lengkap dan spesifik tentang multikultural dan multikulturalisme. Nugraha menyatakan bahwa multikultural secara etimologis dan substantif merupakan pengakuan adanya kelompok lain yang sejajar tanpa menghiraukan perbedaan budaya, agama, atau bahasa. ${ }^{11}$

\section{Multikultural dalam Perjanjian Lama}

Pandangan Perjanjian Lama tentang multikultural terurai dengan jelas dalam narasi Perjanjian Lama. Israel yang merupakan bangsa pilihan Tuhan hidup berdampingan, dan tinggal di tengah masyarakat yang plural. "Ada berbagai bangsa, keyakinan dan agama lainnya berdampingan dengan bangsa ini. Bahkan Abraham, Ishak dan Yakub sebagai nenek moyang Israel telah mengalami perjumapaan dengan bangsabangsa lain."12 Dalam Kejadian 11:31, Abraham dan nenek moyangnya keluar dari negerinya dan menetap di negeri bangsa lain yaitu di Haran. Selanjutnya Abraham berpindah-pindah dan mengalami perjumpaan dengan banyak suku, agama dan bangsa lain, dimana hal yang sama juga dilakukan oleh anaknya Ishak dan Yakub. Hal ini mengkorfirmasi berinteraksi dengan lingkugan multikultural adalah kenyataan yang tidak dapat dilepaskan dari kehidupan manusia sebagaimana juga dijelaskan dalam Perjanjian Lama.

Selanjutnya, kisah bangsa Israel tinggal di Mesir hidup berdampingan dengan banyak bangsa lain juga menjadi bukti mengakarnya multikulturalisme dalam Perjanjian Lama. Peristiwa di Mesir, keluar dari perbudakan Mesir, perjalanan empat puluh tahun di padang gurun, hingga masuk dan menduduki tanah kanaan di bawah kepemimpinan Yosua. Bangsa Israel berinteraksi dengan banyak bangsa dan suku lainnya. Sejarah bangsa Israel dilanjutkan dengan berdirinya kerajaan dan dinasti raja-raja Israel. Pemerintahan Daud dan Salomo berhasil menjadi bangsa yang disegani, hingga dibawah kepemimpinan raja-raja lainnya yang hidup tercela sampai dibuang dalam perbudakan. Bangsa Israel selalau berurusan dengan suku, bangsa, agama lainnya. "Dari kisah bangsa Israel tergambar jelas bahwa ada perjumpaan dengan bangsabangsa lain, walaupun sikap ekslusif dan superior diperlihatkan Israel sebagai bangsa pilihan Allah yang diistimewakan menjadi berkat dan saluran berkat, namun Allah tetap menghukum bangsa Israel ketika tidak taat dan juga bangsa lain yang berontak kepada Tuhan." 13

Perjanjian Lama juga memberikan pesan penting tentang kesadaran multikulturalisme yaitu Dia adalah Allah bagi segenap suku bangsa, ketika Allah memanggiil Yunus untuk pergi ke Niniwe yang berdosa supaya dikabarkan berita pertobatan sehingga mereka tidak menjadi binasa karena kejahatannya. Yunus sepertinya sangat

\footnotetext{
11 Dera Nugraha, "Urgensi Pendidikan Multikultural di Indonesia," Jurnal Pendidikan PKN (Pancasila dan Kewarganegaraan) 1, no. 2 (November 2, 2020): 140-149, https://jurnal.untan.ac.id/index.php/JPPKn/article/view/40809.

12 Stanley R. Rambitan, "Pluralitas Agama Dalam Pandangan Kristen Dan Implikasinya Bagi Pengajaran PAK," Jurnal Shanan 1, no. 1 (March 1, 2017): 93-108, http://ejournal.uki.ac.id/index.php/shan/article/view/1473.

13 Ibid.
} 
enggan dan menolak untuk pergi memberitakan kabar keselamatan dari Allah kepada orang Niniwe, sepertinya Yunus lebih setuju jika Niniwe dibinasakan bukan diselamatkan. Sikap Yunus berbeda dengan Allah, sehingga Allah tetap pada rencana-Nya dengan melanjutkan rancanganNya membawa Yunus pergi ke Niniwe dengan cara Allah sendiri. Dan pada akhirnya Niniwe diselamatkan, "Sekalipun Yunus merasa tidak mungkin Allah mau menyelamatkan Niniwe, karena dalam pemikiran Yunus, Allah hanya mengasihi Israel dan menolak bangsa-bangsa lain."14 Kisah ini memberikan bukti dan penjelasan bahwa Allah memandang semua suku dan agama memiliki kesempatan yang sama untuk diselamatkan. Dan setiap orang dari bangsa manapun harus hidup berdampingan dan menjadi berkat bagi sesamanya tanpa ada sentimen suku, bangsa, bahasa dan agama.

Fakta-fakta lain dalam Perjanjian Lama tentang bagaimana kisah Rut seorang perempuan Moab yang diterima baik dan tinggal bersama dalam lingkungan Israel, menjadi keluarga Israel dan menyembah Allah bahkan menjadi perempuan yang namanya dicatat dalam silsilah Tuhan Yesus Kristus (Mat. 1:5) demikian halnya dengan Raja Koresh yang menjadi orang yang dipakai Tuhan untuk mengerjakan rencanaNya. Koresh, raja negeri Persia hatinya digerakkan TUHAN untuk menggenapkan firman yang diucapkan oleh Yeremia (2Taw. 36:20). Dalam Yesaya 45 Pemakaian Tuhan atas Raja Koresh adalah konfirmasi, bahwa Allah tidak hanya memakai Israel sebagai berkat, tetapi bangsa lain juga jadi berkat bagi Israel. Rambitan memahami bahwa pengakuan atas realitas bangsa lain juga diakui, dimuliakan dan dimanfaatkan oleh Tuhan dengan alasan bahwa negara-negara yang berbeda juga merupakan manifestasi-Nya dan dikasihi Allah ${ }^{15}$

Pandangan Perjanjian Lama tentang bagaimana merespon keberagamana begitu jelas, bahwa keragaman adalah keniscayaan yang dikaruniakan Tuhan yang harus dibangun bukan dihindarkan. Sebab dari sejarah bangsa Israel dipahami bahwa pengakuan Tuhan atas bangsa Israel sebagai Bangsa pilihan tidak mengesampingkan atau mengabaikan keberadaan bangsa-bangsa lain. Perjanjian Lama mengakui eksistensi dan keberadaan semua suku dan bangsa-bangsa lain. Perjanjian Lama mengorfirmasi sebagaimana Allah mengasihi dan ingin menyelamatkan bangsa pilihanNya Israel, hal yang sama juga terjadi atas bangsa lain sebagaimana yang terjadi atas Niniwe. Allah mengasihi dan memberkati semua suku bangsa dan dapat memakai bangsa lain untuk menjadi berkat sebagaimana Koresh raja Persia diapakai Tuhan jadi saluran berkat bagi Israel.

\section{Multikultural Dalam Perjanjian Baru.}

Berbagai informasi dan ajaran tentang bagaimana bersikap menghadapi keberagaman budaya diuraikan dengan jelas dalam Perjanjian Baru. Yesus Kristus sebagai tokoh sentral memberikan berbagai petunjuk, ajaran dan praktek kehidupan. Yesus Kristus adalah patokan setiap orang percaya dalam berpikir, bersikap dan bertindak

${ }^{14}$ Tolop Marbun, “Kajian Konsep Keselamatan Dalam Kitab Yunus," Jurnal Luxnos (2020). 235PAK."

15 Rambitan, “Pluralitas Agama Dalam Pandangan Kristen Dan Implikasinya Bagi Pengajaran 
karena itu menjadi kewajiban dan keharusan untuk memahami berbagai praktek dan kehidupan Yesus Kristus dalam masyarakat multikultural. Sebagaimana dikatakan oleh Rikardo bahwa "Dasar pokok dan utama dari perspektif Kristen pada Perjanjian Baru tentang kesadaran multikulturalisme adalah model yang ditetapkan oleh Yesus Kristus". Hal ini tidak dapat dibantah sebab Yesus atau keKristenan hadir, berkarya dan beredar dimulai dari Kristus, oleh Kristus dan bagi Kristus."16

Respon Kristus kepada masyarakat yang multibudaya pada masa Perjanjian Baru sangat jelas terlihat dalam berbagai pengajaranNya sepanjang pelayananNya. Hukum kasih yang begitu populer sebagai hukum dan nilai universal menjadi salah satu pokok pikiran dan pengajaran Kristus tentang tanggapan Kristus terhadap multikultural, dengan bukan saja hidup mengasihi Tuhan Allah tetapi juga mengasihi sesama manusia selayaknya dia mengasihi diriNya sendiri (Mat. 18:37-40). Pengajaran Kristus tentang kasih yang menjadi tema utama berita injil merupakan ajaran tertinggi tentang multikultural yang terdokumentasi rapi dalam Perjanjian Baru. Mengasihi sesama manusia seperti diri sendiri berarti menghancurkan dan meruntuhkan tembok pemisah perbedaan manusia seperti suku, agama dan ras. Perumpamaan tentang seorang Samaria yang bermurah hati menjadi simbol perlawanan terhadap orang-orang farisi, para Lewi yang mengangap ibadah mereka lebih berkenan kepada Allah dibandingkan dengan orang Samaria. Dalam konsep Kristus bahwa manusia yang paling tinggi derajatnya bukanlah karena kedudukan sosial atau berbagai latar belakang kehidupan yang dapat dibanggakan, tetapi mereka yang mampu menerima sesamanya seperti dirinya sendiri (Luk. 10:25-37). Melalui kisah tentang orang Samaria tersebut, Yesus menyampaikan pikirannya tentang makna multikulturalisme. Ekspresi orang Samaria melewati batas yang selama beberapa waktu menjadi keyakinan, yakni sesama umat manusia tidak hanya orang yang memiliki keyakinan, bangsa, dan agama yang sama tetapi juga setiap orang dengan latar belakang yang dimiliki. ${ }^{17}$

Pengajaran tentang menghargai semua orang tanpa terkait identitas yang melekat dan latar belakangnya juga dijelaskan dari pengajaran Yesus yang menjelaskan bahwa inti dari semua ajaran dalam taurat dan kitab para nabi adalah kemampuan memperlakukan orang lain sebagaimana dikehendaki orang lain perbuat hal tersebut kepada dirinya sendiri (Mat. 7:12). Pandangan Yesus tentang multikultural bukan saja nyata melalui pengajaran-pengajaranNya, namun juga melalui sikap dan praktek hidupNya. Bagaimana Yesus tanpa segan berbincang dengan seorang perempuan Samaria. Dimana pada masa itu sangat jelas bahwa sikap orang Yahudi menolak orang Samaria dan memandang mereka rendah, namun sikap itu ditentang oleh Tuhan Yesus Kristus dengan memberikan waktuNya bercakap-cakap dengan perempuan Samaria. Sikap dan tindakan ini jelas sebagai sebuah sikap dan tindakan yang mencerminkan bahwa Kristus adalah pribadi yang menghargai multikultural. Bagi

\footnotetext{
${ }^{16}$ Rikardo Dayanto Butar-butar et al., "Pengajaran Tuhan Yesus Mengenai Toleransi Dan Implementasinya Ditengah Masyarakat Majemuk" 4, no. 1 (2019): 88-101.

${ }^{17}$ Horbanus Josua Simanjuntak, “Konsep Sesamaku Manusia dalam Lukas 10: 25-37," Voice of Wesley: Jurnal Ilmiah Musik Dan Agama (2020). Hal, 43-53
} 
Yesus semua orang adalah sama, sebagai manusia yang harus dituntun kepada kebenaran tanpa dibebani oleh berbagai latar belakang baik, agama, suku dan bangsanya.

Para rasul sebagai pembawa berita injil Kristus, sebagai representasi Kristus di bumi yang memberitakan injil Kristus ke seluruh dunia, juga memberikan pemikiran dan sikap hidup tentang multikulturalisme. Pandangan para rasul disimpulkan dalam tulisan rasul Paulus dalam Roma 1:1, di mana para rasul begitu yakin berpegang pada Injil, dan injil merupakan menyelamatkan semua orang percaya dimulai dari orang Yahudi, selanjutnya kepada orang-orang Yunani. Pemikiran ini menjadi bukti pandangan para rasul yang memaknai dan menanggapi multikultural dengan baik. Demikian juga dengan pernyataan rasul Petrus yang berkata bahwa; Petrus telah mengerti bahwa Allah tidak memandang muka (Kis. 10:35). Multikulturalisme dalam pandangan, pikiran dan praktek hidup para rasul merupakan pikiran, pandangan dan sikap Kristus yang adalah teladan utama dan tokoh sentral dalam iman Kristen dan Perjanjian baru.

Memahami pengajaran, pikiran, sikap dan praktek hidup Tuhan Yesus Kristus dalam Perjanjian Baru, serta pikiran, sikap dan praktek hidup para Rasul nyata bahwa kebenaran Kristus tidak mengesampingkan atau mengabaikan orang lain dari suku, bangsa dan agama manapun. Meskipun dalam berbagi pemikiran dan praktek hidup Kristus dan para rasul dalam Perjanjian Baru ada usaha memperkenalkan dan menawarkan kebenaran Allah kepada suku bangsa dan agama lain, namun itu tidak menjadi tembok yang membentengi mereka dengan suku bangsa dan agama lainnya. Sebaliknya, Kristus dan para rasul sangat giat menjangkau dan pergi kepada suku, agama dan bangsa lain untuk menjangkau dan memperkenalkan kasih Allah kepada dunia sebagai bukti nyata kasih dan penerimaan mereka kepada suku bangsa dan agama lain. Dalam perspektif Perjanjian Baru memang ada perilaku eksklusif dalam kehidupan multikultural, tetapi Yesus tidak menolak perbedaan, kemajemukan diterima, dipahami dan diakui sebagai sebuah realita. ${ }^{18}$

\section{Konten Pendidikan Agama Kristen Multikultural}

Pendidikan Agama Kristen (PAK) di sekolah bertujuan memberikan pengajaran iman Kristen agar peserta didik bertumbuh dan dapat menjewantahkan imannya dalam kehidupan sehari-hari terhadap lingkungannya. ${ }^{19}$ Peserta didik dalam menerima pendidikan akan berhadapan dengan orang-orang yang berbeda budaya, agama, suku, gaya hidup, sudut pandang dan negara. Berkenaan dengan hal ini Hanum menjelaskan dalam pendidikan multikultural hendaknya siswa disadarkan dalam menerima pengetahuan terdapat bermacam-macam interpretasi dari peserta didik, yang mungkin berlawanan dengan cara pandanganya, sehingga siswa harus menerima perbedaan itu untuk memperkaya pengetahuan atau pengalaman diri. ${ }^{20}$ Lebih spesifik lagi

\footnotetext{
18 Rambitan, "Pluralitas Agama Dalam Pandangan Kristen Dan Implikasinya Bagi Pengajaran PAK."

19 Ya'aman Gulo, Rita Evimalinda, and Ardianto Lahagu, "Peran PAK Dalam Membentuk Mental Positif Generasi Kristen Di Era Millenial," REAL DIDACHE 5, no. 1 (2020): 80-88. https://doi.org/10.31219/osf.io/ryg8z

${ }^{20}$ Farida Hanum, "Pendidikan Multikultural Dalam Pluralisme Bangsa” (n.d.).
} 
Suardana merangkum pemikiran Barekh, Banks, Pazmino, Segler, mengatakan bahwa PAK multikultural dipahamai sebagai cara menempatkan PAK dalam bingkai multikultural, PAK yang pemaknaan kebenaran atau iman harus terurai dalam kebudayaan. ${ }^{21}$ PAK multikultural mengakui eksistensi agama lain dengan menunjukkan keunikan iman Kristen kepada sesama, sehingga ada wujud nyata keluhuran ajaran Kristus yang nilai-nilai pengajaranNya sangat inspiratif dan universal.

Berdasarkan pemahaman di atas, PAK multikultural merupakan usaha membumikan sikap Kristus melalui pendidikan agama Kristen dalam memandang, bersikap dan mampu menerima, mengasihi dan hidup berdampingan dengan semua orang. Dengan pernyataan yang sama, Alakaman mengungkapkan bahwa sikap dan teladan Kristus menjadi dasar pokok PAK Multikultural, sebagaimana Yesus mempraktekkan teladanNya dengan kasih yang melintasi batas sosial, golongan, ras, budaya, agama dan meruntuhkan jurang antara "aku dan engkau" adalah inti dari PAK multikultural." 22 PAK multikultural merupakan pengajaran tentang sikap, pikiran, dan teladan Kristus dalam relasinya dengan semua orang, sehingga setiap orang dapat hidup saling menerima dan hidup berdampingan dalam berbagai perbedaan yang ada. Pengajaran Pendidikan Kristen multikultural menjadikan pluralisme sebagai karakteristik didalam pembelajaran. Shihab dalam Dzakie menyebut pluralisme sebagai sikap toleransi, untuk mencegah terjadinya konflik dengan terlibat aktif dalam usaha menerima perbedaan dan memahami persamaan agar terwujudnya kerukunan. ${ }^{23}$ Oleh sebab itu, pendidik PAK hendaknya memiliki pengetahuan dan wawasan yang cukup mengenai kemajemukan dan keragaman agama di Indonesia.

Kehadiran Pendidikan Agama Kristen di tengah bangsa Indonesia yang multikultural diharapkan memberikan sumbangsih dalam kebangkitan bangsa, karena itu nilai-nilai pengajaran dan kebenaran Kristus yang sangat menghargai perbedaan harus memiliki ruang besar. Perintah mengasihi sesama manusia seperti mengasihi dirinya sendiri (Mat. 22:39) berlaku secara universal tanpa tembok pemisah agama, su$\mathrm{ku}$, ras tertentu, termasuk dalam hal mengasihi dan mendoakan musuh (Mat. 5:44), sikap dan praktik hidup Kristus dengan singgah di rumah Zakheus (Luk. 19:5), berdiskusi dengan perempuan Samaria (Yoh. 4), dapat menjadi referensi pendidikan Agama Kristen sebagaimana yang juga dipraktikkan para rasul.

Tuhan Yesus Kristus sebagai pusat, teladan, dan patokan hidup berpikir, bersikap dan berperilaku orang percaya datang dengan ciita-cita mulia yakni supaya semua orang memiliki hidup dalam segala kelimpahan (Yoh. 10:10b). Pendidikan Agama Kristen sebagai salah satu ujung tombak pemuridan dan pemberitaan firman Kristus harus disampaikan sesuai dengan pikiran, sikap dan perilaku Kristus dalam

${ }^{21}$ I Made Suardana, "Mengurai Landasan Konseptual PAK Berbasis Multikultural Dalam Konteks Indonesia," Kurios 6 (2020),346-366 . https://www.sttpb.ac.id/ejournal/index.php/kurios/article/view/150.

${ }^{22}$ Marlen Tineke Alakaman, "Relevansi Sikap Multikultural Yesus dalam Injil Lukas," KenosiS: Jurnal Kajian Teologi 2, no. 2 (December 2018): 160-179.

${ }^{23}$ Fatonah Dzakie, "Meluruskan Pemahaman Pluralisme Dan Pluralisme Agama Di Indonesia," Al-Adyan:Jurnal Studi Lintas Agama (2014), 79-94 http://ejournal.radenintan.ac.id/index.php/alAdyan/article/view/1408/1114. 
mengahadapi keberagaman.

\section{Pendidikan Agamam Kristen untuk Kedamaian}

Konten Pendidikan Agama Kristen multikultural juga didesain supaya mempererat semangat kebhinekaan. Iman Kristen yang ekslusif bukan menolak dan meremehkan sesama, tetapi mengembangkan sikap menerima semua orang sebagai sesama sehingga bisa mewujudkan cita-cita luhur semangat kebangkitan nasional dan sumpah pemuda. PAK multikultural pengajarannya diperkaya dengan menaburkan benih-benih perdamaian karena sejatinya orang percaya hadir untuk membawa damai di bumi (Mat. 5:9). Hasil penelusuran Sidjabat terhadap buku karya Andar, bahwa untuk menjadi pembawa damai di tengah masyarakat, seseorang harus lebih dulu diperdamaikan dengan Allah, melalui Kristus Yesus (2Kor. 5:19; Kol. 1:20; 1Yoh. 2:2).24 Semangat perdamaian adalah yang menjadi salah satu intisari dari PAK Multikultural, di mana ajaran Kristus sebagai pembawa damai menjadi nafas yang harus dihembuskan kepada setiap orang dalam perbedaan. Dalam PAK multikultural praktik dan teladan Kristus dalam mengampuni, memaafkan tidak merasa diri sendiri paling benar, menjadi dasar yang harus dikembangkan sehingga bisa mendorong terwujudnya kedamaian karena setiap orang berusaha mengembangkan sikap menghormati, menjaga harmoni dengan sesama dalam komunitas sosial, mengampuni dan menyingkirkan pikiran merasa benar sendiri.

Hal senada dinyatakan Darmawan, bahwa PAK memberikan pengajaran, di dalam Yesus seluruh manusia dapat berdamai dengan Pencipta, setelah itu berdamai dengan diri sendiri, dan berdamai dengan orang di luar dirinya. Sehubungan dengan itu, ada suatu penegasan yang perlu dipikirkan oleh individu agar setiap orang tidak boleh ditandai sifatnya, baik wajah jelek, layak, tidak kompeten bergantung pada agama, posisi sosial ${ }^{25}$, sehingga kedamaian yang dicita-citakan dapat terwujud. Dengan situasi yang kondusif dan damai, masyarakat akan menjadi produktif dan konsentrasi, dapat berkarya dan berusaha semaksimal mungkin, sehingga cita-cita kebangkitan nasional akan terwujud dalam lingkup yang lebih luas.

\section{Pendidikan Agamam Kristen untuk Kerukunan}

Peindidikan Agamam Kristen multikultural harus disampaikan dengan pengakuan terhadap esksistensi agama lain sebagaimana sikap dan pandangan Kristus. PAK hadir dalam dimensi iman yang ekslusif ke dalam, namun terbuka dan menerima perbedaan ke luar, bukan ber-sikap ekslusivisme yang buta, yang dapat merongrong persatuan kesatuan bangsa. Sehingga, sebagai sesama anak bangsa tidak ada perbedaan dan sentimen atas nama suku, ras dan agama. Ajaran yang selaras dengan apa yang dikatakan oleh dalam Perjanjian Baru yakni menghormati setiap orang (1Ptr. 2:17), Allah tidak memandang muka (Gal. 2:6), setiap orang punya kesempatan yang sama menerima berita injil (Rm. 1:16).

Hidup rukun bersama orang lain di tengah kemajemukan agama dapat diwujud-

${ }^{24}$ Binsen S. Sidjabat, Mendidik Warga Gereja Melalui Seri Selamat (Jakarta: BPK Gunung Mulia, 2018).hsl. 310

25 I Putu Ayub Darmawan, "Pendidikan Perdamaian Dengan 12 Nilai Dasar Perdamaian," BIA': Jurnal Teologi dan Pendidikan Kristen Kontekstual 2, no. 1 (June 2019): 55-71. 
kan bilamana umat Tuhan (dalam hal ini nara didik) memiliki gaya hidup inkarnasi Yesus. ${ }^{26}$ Bimo S. Utomo mengungkapkan bahwa karakteristik inkarnasi dan pengorbanan Kristus harusnya mampu menciptakan teladan bagi orang percaya untuk dapat saling mengasihi, di mana sikap yang paling mendasar untuk menciptakan kasih yang rela berkorban adalah dengan cara melihat kepentingan bersama lebih utama dari kepentingan pribadi, saling memahami dan menghormati antara satu dengan yang lain. ${ }^{27}$ Oleh karena itu, pembelajaran pendidikan Agama Kristen yang pro terhadap prulalitis harus diselenggarakan dengan peningkatan kesadaran berbangsa yang multikultural, hati yang terbuka terhadap perbedaan dan ketundukan kepada pemerintah sebagai wakil Tuhan (Rm. 13:1-8). PAK multikultural harus disampaikan dengan gagasan untuk meningkatkan nilai kasih universal kepada semua orang (1Kor. 13), sehingga mampu menerima perbedaan dan dapat bersosialisasi ditengah masyarakat yang majemuk.

\section{Pendidikan Agamam Kristen untuk Kemakmuran}

Semangat kebangkitan nasional dapat diwujudkan melalui pendidikan Agama Kristen multikultural. PAK multikultural hadir bukan untuk mendominasi keyakinan lain, atau meragukan ekslusivitas iman dalam Kristus. Namun, PAK multikultural mengakui eksistensi agama lain, sehingga sikap menghormati dan mengahargai ajaran agama lain terus berkembang tanpa mengerdilkan keunikan iman Kristen sebagaimana pikiran, sikap, dan praktik hidup Yesus, PAK multikultural disampaikan dengan pendekatan konstrukif di mana dalam kontennya PAK ada untuk mendorong orang percaya mengambil perannya untuk bertanggungjawab bagi kesejahteraan kota dimana dia tinggal. (Yer. 29:7). PAK multikultural kontennya harus diwarnai kehadiran orang percaya yang ada untuk menggarami, menerangi sekeliling di mana ia hidup dan berinteraksi (Mat. 5:13,15). Membangun dan menyadarkan orang percaya untuk bertanggung jawab atas kesejahteraan dan kemakmuran bangsanya akan membangkitkan semangat individu mewujudkan kehidupan yang makmur dan sejahtera, dengan mengembangkan semua potensi diri, kreativitas diri, dan segala kemampuan untuk hidup menjadi berkat dan memberi dampak kepada kebangkitan sekelilingnya. Sidjabat mengutip karya Andar yang menuliskan umat Tuhan harus mengembangkan karunia dan talenta yang diberikan Tuhan, untuk mendatangkan kesejahteraan di tengah masyarakat majemuk. Dengan menjadi berkat dalam aspek material, sosial, spiritual, politis. ${ }^{28}$

\section{PAK untuk toleransi}

Alkitab mencatat, bahwa sejak awal Kekristenan berusaha untuk hidup di antara budaya, agama, tradisi filosofis yang beragam, dan berupaya untuk menanggapi tantangan multikultural pada zamanya, dan ini terurai dalam pada kitab PL maupun PB. Pengajaran ini hendaknya terus menjadi pusat pembelajaran agama Kristen da-

\footnotetext{
${ }^{26}$ Binsen S. Sidjabat, Mendidik Warga Gereja Melalui Seri Selamat.

27 Bimo Setyo Utomo, “Trilogi Persaudaraan Yang Rukun Menurut Mazmur 133: Sebuah Nasehat, Dasar, Dan Berkat,” Jurnal Teologi Gracia Deo 1, no. 2 (January 2019): 101-113.

28 Binsen S. Sidjabat, Mendidik Warga Gereja Melalui Seri Selamat.
} 
lam membangun kesadaran akan kemajemukan yang dimiliki bangsa. Sikap terbuka, menerima dan lapang dada terahadap perbedaan keyakinan adalah sikap toleransi yang harus dikembangkan, pikiran dan praktik tersebut bukan saja sesuai dengan firman Tuhan, namun merupakan pikiran dan praktik hidup Kristus sebagai tokoh sentral iman Kristen. PAK Multikultural mendorong orang percaya untuk mampu bersikap terbuka dan memperlakukan orang dari agama dan kepercayaan manapun seperti dirinya sendiri. Identitas sebagai murid Kristus nyata dari kemampuan menerima orang lain dalam perbedaan (Yoh. 13:35; 15:17), dengan tegas Yesus memberikan perintah mengasihi sesama.

Dari berbagai perintah Tuhan Yesus tentang mengasihi sesama memiliki makna dan pengertian yang maksimal tentang sikap orang percaya terhadap agama lain. Semua orang adalah sesama bagi orang percaya, karena itu sikap intoleransi sangat diharamkan dan toleransi wajib di junjung tinggi dalam paraktek berpikir dan bertindak terhadap orang lain. Sikap ini diuraikan jelas dalam cerita tentang seorang Samaria yang murah hati (Luk. 10:25-37). Penerimaan Kristus kepada perempuan Samaria adalah aksi nyata Tuhan Yesus menolak intoleransi dan mengembangkan semangat dan sikap toleransi (Yoh. 4:9). Terkait hal ini, Butar-butar menjelaskan kisah keterbukaan Yesus terhadap perempuan Samaria disampaikan pesan dan ajaran bahwa Yesus tidak pernah setuju dengan perbuatan intoleransi. Bagi Tuhan Yesus semua orang memiliki kedudukan dan derajat yang sama. Penerimaan terhadap perempuan Samaria adalah pesan dan ajaran, bahwa tidak ada suku bangsa, ras, kelompok, atau agama yang lebih rendah dari yang lainnya. ${ }^{29}$ PAK untuk toleransi bukan sebuah pilihan, namun sebuah keharusan yang wajib dikembangkan dalam seluruh kehidupan orang percaya. Sebab, hal tersebut merupakan ajaran utama Alkitab, dan sikap teladan hidup, serta perintah langsung Tuhan Yesus Kristus.

\section{Relevansi Pendidikan Agama Kristen Multikultural dalam Membangun Semangat Kebangkitan Nasional}

Dalam pembelajaran agama Kristen hendaknya menerapkan pendekatan konstruktif. Shymansky yang dikutip oleh Suparlan, menjelaskan pendekatan konstruktif adalah aktivitas di mana siswa mengumpulkan wawasan mereka sendiri, mencari pentingnya jati diri, untuk menyelesaikan ide dan pemikiran baru yang dimilikinya. ${ }^{30}$. Sehingga, dalam belajar siswa memiliki kepekaan, kemandirian berpikir sendiri bertanggung jawab, mengembangkan diri dengan segala potensi yang dimiliki melalui proses dan pengalaman belajar yang berkesinambungan, serta dapat berintegrasi dalam penyelesaian berbagai masalah agar tercipta kelestarian lingkungannya. Sekolah adalah tempat untuk mengajarkan dan memahami, bahwa setiap orang mengetahui apa yang semua diperlukan dalam fakta kemajemukan yang ditemukan di lingkungannya.

Tanpa menyangkal ikatan budaya dan realitas yang sangat besar dari para

\footnotetext{
${ }^{29}$ Butar-butar et al., "Pengajaran Tuhan Yesus Mengenai Toleransi Dan Implementasinya Ditengah Masyarakat Majemuk."

${ }^{30}$ Suparlan, "Teori Konstruktivisme Dalam Pembelajaran," ejournal STIT Palapa Nusantara Lombok NTB (n.d.), https://ejournal.stitpn.ac.id/index.php/islamika/article/download/.
} 
siswa, tradisi keluarga, nilai-nilai komunitas, asal-usul etnik, keyakinan agama, cara hidup kelas sosial tertentu, guru PAK harus membantu nara didik menyadari bahwa ada banyak cara berbeda untuk membangun diri sendiri, berhubungan dengan masyarakat, dan menggunakan bahasa secara efektif. Kemampuan untuk menempatkan diri dalam konteks lain, dan mengadopsi sudut pandang metodologis yang berbeda dari sudut pandangnya sendiri mutlak diperlukan agar dapat menyambut perbedaan. Persyaratan perluasan konten pembelajaran harus mengkaji berbagai cara hidup, lingkungan sosial-ekonomi, tradisi, di masyarakat dengan memperhitungkan multikultural yang dijelaskan sebelumnya. Jadi, sangat penting memperluas konten pembelajaran PAK di lingkungan sekolah akrab dengan pendekatan fenomena global, bahkan universalis.

Pemahaman dan respon yang benar terhadap tantangan multikultural agama perlu ditanamkan pada siswa, bahwa iman Kristen dapat menjadi benar bagi penganutnya namun tidak harus menjadi benar bagi setiap orang. Untuk mengaku Yesus sebagai Tuhan dan Juruselamat, dan menyembah-Nya dengan cara yang digunakan di gereja adalah benar-benar layak sebagai pernyataan kesetiaan, tetapi tidak memberikan hak untuk membuat klaim yang sama di luar kehidupan dan peribadatan gereja. Kristus adalah Tuhan dan juga Juruselamat, orang-orang lain dengan kesungguhan yang sama mengharapkan nama-nama lain sebagai pengikutnya. Newbigin menegaskan, apa yang menjadi masalah bukanlah isi faktual dari klaim-klaim iman, melainkan kesungguhan dalam memegang klaim-klaim itu. Klaim-klaim itu tidak untuk mengajarkan dan memahami, bahwa setiap orang mengetahui apa yang diperlukan dalam kemajemukan di lingkungannya. Kepercayaan atau iman adalah masalah pribadi. Setiap orang mempunyai iman pribadinya sendiri, sebagaimana Rambitan dalam tulisannya berpendapat bahwa umat Kristiani dalam menghadapi kemajemukan agama, model inklusif (menganggap agama yang berbeda mengandung kebenaran yang sama), dan multikulturalisme harus jadi pilihan (agama yang berbeda adalah tempat Tuhan menyingkapkan diriNya), sehingga para naradidik harus didorong untuk merumuskan kembali filosofi agama melalui pengalaman dalam kehidupan multikultural tersebut. ${ }^{31}$

Dengan demikian, cita-cita kebangkitan nasional dapat diwujudkan, karena PAK multikultural memberikan sumbangsih membangun harmoni sebagai sesama anak bangsa. Perhatian terhadap kemajemukan bangsa tidak hanya sampai pada derajat menerima kehadiran agama yang berbeda, tetapi pada saat yang sama dibutuhkan untuk membangun kerjasama dan hubungan yang lebih luas dalam hidup bermasyarakat tanpa menghilangkan identitas iman sebagai orang Kristen

\section{KESIMPULAN}

Semangat kebangkitan nasional di masa kini dimaknai sebagai kesempatan untuk melakukan berbagai macam perubahan demi kehidupan yang lebih baik. Pendidikan Kristen tidak secara lugas membahas materi semangat kebangkitan nasional, PAK."

\footnotetext{
${ }^{31}$ Rambitan, “Pluralitas Agama Dalam Pandangan Kristen Dan Implikasinya Bagi Pengajaran
} 
namun aspek nilai-nilai kebangkitan nasional ada pada pendiidkan Kristen yang didasari Alkitab sebagai sumber belajar utamanya, secara khusus pendidikan Kristen disekolah (PAK). PAK Multikultural merupakan istilah yang digunakan untuk memberikan gambaran dan uraian tentang usaha membumikan sikap Kristus melalui pendidikan agama Kristen, dalam memandang, bersikap, dan mampu menerima, mengasihi, serta hidup berdampingan dengan semua orang. Beberapa pokok pikiran dapat disajikan sebagai konten pendidikan Kristiani. Pendidikan Kristen untuk kedamaian, yaitu penegasan bahwa di dalam Kristus Yesus seluruh umat manusia dapat berdamai dengan Tuhan, lalu berdamai terhadap pribadinya sendiri, dan orang di luar dirinya. Berikutnya, PAK untuk kerukunan, di mana PAK harus disampaikan dengan gagasan untuk meningkatkan nilai kasih universal kepada semua orang sehingga mampu menerima perbedaan, serta dapat bersosialisasi di tengah masyarakat yang majemuk. Lalu, PAK untuk kemakmuran, di mana PAK disampaikan dengan pendekatan konstrukif, yang kontennya adalah dorongan untuk bertanggung jawab bagi kesejahteraan kota bahkan bangsanya. Dan, konten PAK untuk toleransi, di mana yang disampaikan merupakan ajaran utama Alkitab dan perintah langsung Tuhan Yesus Kristus. Sebab itu semua sikap dan aksi intoleransi harus ditolak, sebaliknya, mengembangkan sikap toleransi.

Dengan demikian, Pendidikan Agama Kristen hadir memberikan inspirasi kepada peserta didik dan sesamanya untuk mengalami kebangkitan bersama menuju bangsa yang kuat, yang mengalami perubahan lebih baik sesuai dengan harapan bangsa Indonesia. Untuk mewujudkannya, guru dalam mengajar PAK hendaknya meningkatkan model pendekata konstruktif, sehingga membangun kesadaran peserta didik tentang realitas perbedaan di sekeliilingnya. Konten PAK tidak sekedar membina naradidik menjadi orang Kristen yang saleh, namun dalam pembelajaran konstruktif ada upaya membangkitkan kesadaran bahwa PAK harus mendorong siswa membawa pesan dan teladan Kristus. Maka, di masa kini, peserta didik akan mengalami kebangkitan individu-individu yang berimplikasi kepada kebangkitan bersama sebagai bangsa.

\section{REFERENSI}

ALAKAMAN, MARLEN TINEKE. "RELEVANSI SIKAP PLURALIS YESUS DALAM INJIL LUKAS." KENOSIS: Jurnal Kajian Teologi 2, no. 2 (December 2018): 160-179.

Binsen S. Sidjabat. Mendidik Warga Gereja Melalui Seri Selamat. Jakarta: BPK Gunung Mulia, 2018.

Butar-butar, Rikardo Dayanto, Ester Lina Situmorang, Jabes Pasaribu, and Manahan Uji. "Pengajaran Tuhan Yesus Mengenai Toleransi Dan Implementasinya Ditengah Masyarakat Majemuk" 4, no. 1 (2019): 88-101.

Darmawan, I Putu Ayub. "Pendidikan Perdamaian Dengan 12 Nilai Dasar Perdamaian." BIA': Jurnal Teologi dan Pendidikan Kristen Kontekstual 2, no. 1 (June 2019): 55-71.

Dzakie, Fatonah. "Meluruskan Pemahaman Pluralisme Dan Pluralisme Agama Di Indonesia." Al-Adyan:Jurnal Studi Lintas Agama (2014). 
Gulo, Ya'aman, Rita Evimalinda, and Ardianto Lahagu. "Peran PAK Dalam Membentuk Mental Positif Generasi Kristen Di Era Millenial." REAL DIDACHE 5, no. 1 (2020): 80-88.

Hamid, Edy Suandi. "Peran Pendidikan Untuk Mengukuhkan Nasionalisme Dan Membangun Karakter Bangsa." UNISIA 34 (2012).

Hanum, Farida. "Pendidikan Multikultural Dalam Pluralisme Bangsa" (n.d.).

Husda, Husaini. "Rekonstruksi Sejarah Kebangkitan Nasional." Jurnal Adabiya 21, no. 2 (March 2020): 31.

Marbun, Tolop. "KAJIAN KONSEP KESELAMATAN DALAM KITAB YUNUS." JURNAL LUXNOS (2020).

Muawanah, Siti. "NASIONALISME MELALUI PENDIDIKAN AGAMA PADA PESERTA DIDIK SMA/SMK/MA DI WILAYAH PERBATASAN KALIMANTAN BARAT." SMART 1, no. 2 (December 2015).

Nugraha, Dera. "URGENSI PENDIDIKAN MULTIKULTURAL DI NDONESIA." Jurnal Pendidikan PKN (Pancasila dan Kewarganegaraan) 1, no. 2 (November 2020): 140.

Rambitan, Stanley R. “Pluralitas Agama Dalam Pandangan Kristen Dan Implikasinya Bagi Pengajaran PAK." Shanan: Jurnal Pendidikan Agama Kristen (2017).

Santoso, Ayi B, and Supriatna. Sejarah Pergerakan Nasional (Dari Budi Utomo 1908 Hingga Proklamasi 1945). Bandung: UPI Bandung, 2018.

Saragih, Erman Sepniagus. "Pendidikan Agama Kristen Berbasis Wawasan Kebangsaan.” Teologi Cultivation, Institut Agama Kristen Negeri Tarutung 2, no. 2 (2018).

Siahaan, Harls Evan. "Mengajarkan Nasionalisme Lewat Momentum Perayaan Paskah: Refleksi Kritis Keluaran 12:1-51." DUNAMIS Jurnal Teologi dan Pendidikan Kristiani) Vol 1, no. 2 (2017): 39-54. www.sttintheos.ac.id/ejournal/index.php/dunamis.

SIMANJUNTAK, HORBANUS JOSUA. "KONSEP SESAMAKU MANUSIA DALAM LUKAS 10: 25-37." Voice of Wesley: Jurnal Ilmiah Musik dan Agama (2020).

Suardana, I Made. "Mengurai Landasan Konseptual PAK Berbasis Multikultural Dalam Konteks Indonesia." Kurios 6 (2020).

Suparlan. "TEORI KONSTRUKTIVISME DALAM PEMBELAJARAN." ejournal STIT Palapa Nusantara Lombok NTB (n.d.).

Thoha, Anis Malik. Tren Pluralisme Agama: Tinjauan Kritis. Jakarta: Perspektif Kelompok GEMA INSANI, 2005.

Utomo, Bimo Setyo. "Trilogi Persaudaraan Yang Rukun Menurut Mazmur 133: Sebuah Nasehat, Dasar, Dan Berkat." JURNAL TEOLOGI GRACIA DEO 1, no. 2 (January 2019): 101-113.

Yuliatri, Rury. "Membangun Semangat Kebangkitan Nasional Melalui Pendidikan" (n.d.).

“Jejak Kebangkitan Nasional." Arsip Media Kearsipan Nasional (2014).

"Religious Plurality and Christian Self-Understanding." Word Council of Churches, n.d. 